\title{
Cyperus Iria: An Overview
}

\author{
Malavika T M, Sarathlal P S, Dr. Ajith Babu T K, Poornima M \\ Malik Deenar College of Pharmacy
}

\begin{abstract}
Cyperus iria, the plant that comes under the category of sedges. They will grow where it is not desired. Cyperus species were traditionally used to treat various clinical conditions. Currently, it is one of the most widespread, problematic and economically damaging agronomic weeds, growing widely in various tropical and subtropical regions of the world. Cyperus iria is also known as rice flatsedge as the plant commonly occurred in rice fields. The plant is a rich source of phenols and alkaloids. Many previous studies showed that the plant exerted antioxidant, antimicrobial, anticancer activity, antiinflammatory, anthelmintic and others. This review was designed to highlight the pharmacological effects of Cyperus iria.
\end{abstract}

Keywords: Cyperus iria, sedges, weed.

\section{INTRODUCTION}

$\mathrm{H}$ erbs are used as traditional medicine as long as the history of mankind. The term "herb" are plants, some parts of which contain essential oils useful in food, medicine and / or cosmetics and which usually grow in temperate regions, both in the wild and under cultivation[1]. Active ingredients extracted from medicinal plants are used in synthesis of different drugs[2]. Traditional system of medicine is widely practiced to treat health disorders for 80 percent of people worldwide as per WHO. According to WHO, around 2100 plants species are being used as medicinal plants[3]. Potent, inexpensive and safe drugs can be produced from plants of natural origin[4].

Grasses, sedges and rushes all belongs to cyperaceae family. They have similar characteristics and so they are confused with each other. Plants under sedges are undesirable at one place and desirable at another place. Either dense clumps or tufts are formed by sedges and are particularly associated with wetlands. The plants under the category of sedges will compete with other plant crops such as rice paddies, soyabean plant for plant nutrients, soil moisture,space and sunlight. Thus, they are considered as most common agricultural weed. Even though they are said to have many uses. They can be used as food, as fuel, in horticulture and for traditional uses. Also, have many pharmacological activities such as antioxidant properties, antibacterial, antifungal, antidiabetic, anticancer properties and so on[5].

\section{SYNONYM[6]}

- Chlorocyperus iria Rikl

- Cyperus microiriaSteud

- Cyperus santoniciRottb

- Cyperus microlepis Baker

- Cyperus panicoides Lam

\section{III.COMMON NAMES[7]}

\section{Preferred common name}

Rice flatsedge

\section{International common name}

Grasshopper's Cyperus (English)

\section{Local common names}

Bangladesh - barachucha

Cambodia - kakkangkep

India - morphula

Indonesia - dekengwangin, djekeng

Japan - kogomegeyatsuri

Korea, DPR - chambang-donsani

Malaysia - rumputmenderong

Nepal - chow, guchen,mothey,ochumani

Pakistan - khana

Philippines - alinang, ballayang,taga-taga

Thailand - kokhuadaeng, yaarangkaakhaac

USA - rice flatsedge

Eppo code - CYPIR (Cyperus iria)

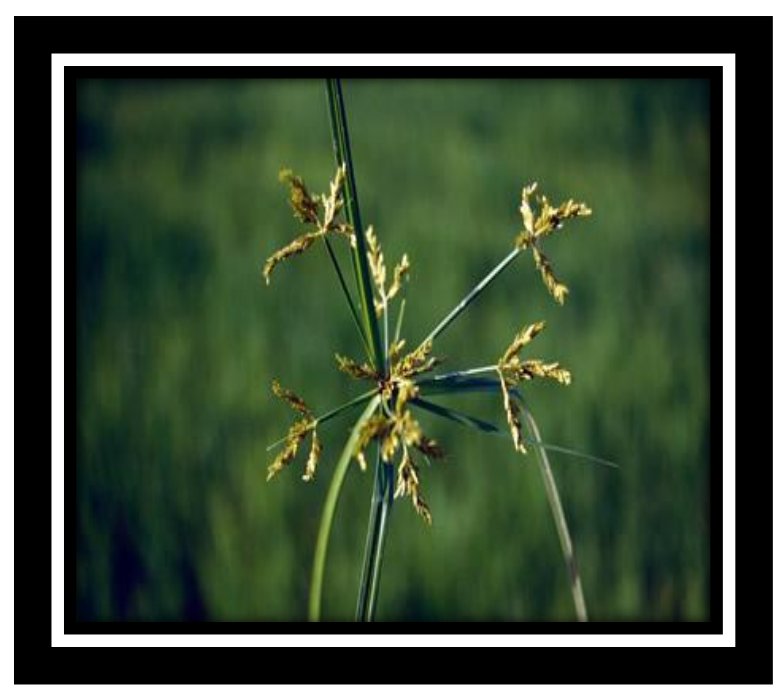

Figure 1: CYPERUS IRIA

IV.TAXONOMIC TREE[7]

Domain: Eukaryota 
Kingdom: Plantae

Phylum: Spermatophyte

Sub Phylum: Angiospermae

Class: Monocotyledonae

Order: Cyperales

Family: Cyperaceae

Genus: Cyperus

Species: Cyperus Iria

\section{DISTRIBUTION[6]}

Asia: China (including Taiwan), Japan and Korea

South and South East Asia: Bangladesh, Cambodia, India, Indonesia, Lao PDR, Malaysia, Myanmar, Nepal, Pakistan, Philippines, Sri Lanka, Thailand and Vietnam

Rest of world: Australia, Fiji, Swaziland, West Africa

\section{REPRODUCTION[8]}

Cyperus iria reproduces from seed which may be dormant but can germinate about 75 days after shedding. One plant may produce around 3000 to 5000 seeds. The seedlings appear soon after rice is sown, the flowers appear in about one month, shed their seeds and may establish a second generation in the same season.

\section{DESCRIPTION[6,7]}

It is a tufted annual herb or occasionally perennial, with fibrous roots and height varies from 8 to $60 \mathrm{~cm}$.

General habit: Erect tufted sedge

Root: Numerous, short \& yellowish red

Stem: Numerous, short, sharply 3 angled, smooth, yellowish red, 5-80 $\mathrm{cm}$ high

Leaf: Linear- lanceolate, basal, rough to touch in upper part, flaccid with gradually tapering point and 3-8 $\mathrm{mm}$ wide

Leaf sheath: Green to reddish brown, membraneous, enveloping the stem at base

Inflorescence: Simple or compound, usually open, 1-20 cm long with groups of spikes which are either sessile or on 0.5 $15 \mathrm{~cm}$ long penduncles (rays)

Inflorescence bracts (involucre): Leafy, 3-5, the lower one longer than the inflorescence, 5-30 cm long, 1-6 mm wide

Spike: Sessile or almost so, elongate \& rather dense

Spikelets: Erect-spreading, crowded

Flower: Glumes are broad-ovate, golden brown, 2 or 3 stamens

Style: Branched
Fruit: Three-angled, 1.0-1.5 mm long, 0.6-0.7 mm wide, obovate, triangular in cross section, nut with slightly concave sides \& shiny dark brown to almost black in colour

\section{PHARMACOLOGICAL EFFECTS}

\subsection{Antioxidant Activity[9]}

\subsubsection{Teac Antioxidant Activity Determination}

Methanolic and aqueous plant material extracts were prepared. By using potassium peroxodisulphite, 2,2-azinobis(3-ethyl benzothiazoline)-6-sulphonic acid (ABTS) aqueous solution was oxidized and kept aside for $16 \mathrm{hrs}$ at room temperature. Then diluted with $95 \%$ ethanol to an absorbance of $0.75 \pm 0.05$ at $734 \mathrm{~nm}$. The oxidized $\mathrm{ABTS}^{+}$solution was mixed in $20 \mu \mathrm{l}$ of each sample and measured the absorbance at $734 \mathrm{~nm}$. Trolox was used as reference standard. A standard curve was constructed for Trolox at different concentrations. The results were expressed as $\mu \mathrm{M}$ Trolox $/ \mathrm{mg}$ dry weight of plant material. And the TEAC value for water extract was found to be $762.04 \pm 33.80$ whereas TEAC value for methanolic extract was found to be $769.41 \pm 53.57$.

\subsubsection{Total polyphenol content determination}

Methanolic and aqueous plant material extracts were prepared.To $200 \mu \mathrm{l}$ distilled water and $40 \mu \mathrm{l}$ of folin-ciocalteu reagent, $20 \mu \mathrm{l}$ of each extract $(125 \mu \mathrm{g} / \mathrm{ml})$ was added and kept at room temperature for $5 \mathrm{~min}$. Then $40 \mu \mathrm{l}$ of $20 \%$ sodium carbonate was added to the mixture. The resulting blue complex was then measured at $650 \mathrm{~nm}$. Catechin was used as standard for calibration curve. The total polyphenol content is expressed as $\mu \mathrm{g}$ of catechin equivalent per milligram of dry weight. The result shows that the total polyphenol content for water and methanolic extract was found to be $385.67 \pm 5.62$ and $345.25 \pm 9.81$ simultaneously.

\subsection{Anti-Bacterial Activity[10]}

Anti-bacterial activity was done by disc diffusion method in root extract of Cyperus iria.Escherichia coli, staphylococcus aureus \& salmonella typhi strains were used.Nutrient broth was prepared as inoculum, sterilized, inoculated with inoculum and kept in incubator at $37^{\circ} \mathrm{C}$ for $24 \mathrm{hrs} .1 \mathrm{ml}$ of prepared inoculum was poured in sterile petri dish. Then $15 \mathrm{ml}$ of nutrient agar media (NAM) was poured in it and allowed to solidify.After solidification the disc of whatman filter paper with $20 \mu \mathrm{l}$ plant extracts were carefully placed at the center of petri dish. After incubation the zone of inhibition (ZOI) was measured. The result showed excellent antibacterial activity against all tested bacterial strains. The zone of inhibition for n-hexane extract against Escherichia coli, staphylococcus aureus \& salmonella typhiwas found to be $18.25 \pm 0.76,21.25$ \pm 0.76 and $25.25 \pm 0.11$ simultaneously. In turn, ZOI for ethyl acetate extract was found to be $17.25 \pm 0.51,12.45 \pm 0.51$ and $11.25 \pm 0.12$ respectively. From this it shows that, root $n-$ hexane extract samples have potential bacterial activity against staphylococcus aureus, salmonella typhi compared 
with E. coli in turn, compared with extract of ethyl acetate, nhexane extract having more anti-microbial ingredients.

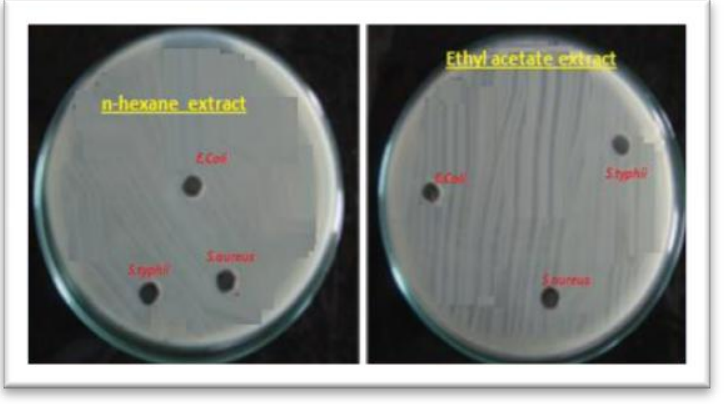

Figure 2: Antibacterial activity of n-hexane \& ethyl acetate root extract of Cyperus iria against escherichia coli, staphylococcus aureus \& salmonella typhi.

\subsection{Anti-Fungal Effect[11]}

Chopped leaves of Cyperus iria were placed on the lid of petri dishes, with potato dextrose agar (PDA) as culture medium on dish bottom. The PDA plates had each been inoculated with one of three fungal species including; Fusarium oxysporum, Fusarium graminearum\&Fusarium solani. The inverted petri dishes were incubated at $24^{\circ} \mathrm{C} \&$ the diameter of each fungal colony was recorded daily until the mycelium reached the edge of the petri dish. The result shows that volatiles emitted from the leaves of Cyperus iriasignificantly inhibited the mycelial growth of Fusarium graminearum, with an inhibition rate of $8.96 \%$ (Figure 3A). Volatiles emitted from Cyperus iria did not inhibit growth of other fungal species in Fusarium (Figure 3B,C).

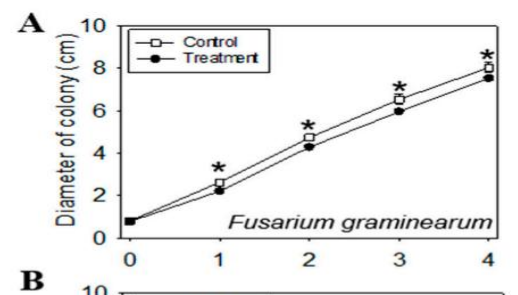

$\mathbf{B}$

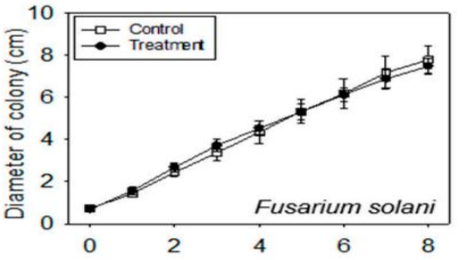

C

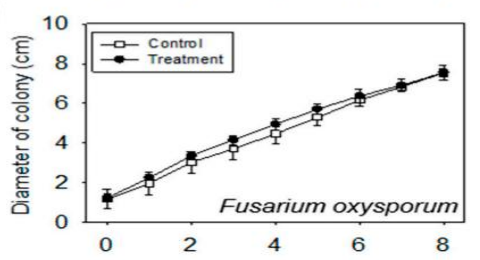

Figure3: Daily antifungal effect of volatiles from Cyperus iria leaves to Fusarium species until the mycelium reached the edge of the petri dish: Fusarium graminearum(A), Fusarium solani $(\mathbf{B})$ and Fusarium $\operatorname{oxy} \operatorname{sporum}(\mathbf{C})$.

\section{REFERENCE}

[1] K.V.Peter, World Noni Research Foundation, India and K.Nirmal Babu, Indian Institute of Spices Research, India- Introduction to herbs and spices: medicinal uses and sustainable production/Woodhead Publishing Limited, 2012

[2] Rasool Hassan, Pharmaceut Anal Acta 2012, vol 3/issue 10medicinal plants

[3] Reelsaltlife.blogspot.in/2012/02/role-of-herbs-in-human-life.html

[4] Kokatae CK. Practical Pharmacognosy. 4th ed. Delhi: Vallabh prakashan; 2008.21

[5] Gudisa Kishore, GurralaAlluraiah-Phytochemical screening and antimicrobial assessment of Cyperus iria (L) weeds roots, Bulletin of Pharmaceutical and Medical Sciences (BOPAMS) vol.1.Issue.2, 2013

[6] www.knowledgebank.irri.org/training/fact-sheets/item/cyperusiria

[7] Cyperus iria- Invasive compendium/CABI/Cabi.org/isc/datasheet

[8] Cyperus iria L/species/WIKTROP Portal v2.0

[9] Yu-Ling, Shyh-Shyun Huang, Jeng-Shyan Deng, Yaw-Huei Lin, Yuan-Shiun Chang \& Guan-Jhong Huang -invitro antioxidant properties and total phenolic content of wetland medicinal plants I Taiwan / Botanical Studies, Vol.53 (2012)53: 55-66 Biochemistry

[10] Gudisa Kishore, GurralaAlluraiah-Phytochemical screening and antimicrobial assessment of Cyperus iria (L) weeds roots, Bulletin of Pharmaceutical and Medical Sciences (BOPAMS) vol.1.Issue.2, 2013

[11] Yifan Jiang, Bonnie H Ownley, Feng chen - Terpenoids from weedy ricefieldflatsedge (Cyperus iria) are developmentally regulated and stress-induced, and have antifungal properties/Molecules 2018, 23, 3149 - MDPI/journal/Molecules 